\title{
EKSTRAK ETANOLIK DAUN Gynura procumbens (Luor) Merr. MENGHAMBAT PROLIFERASI SEL KANKER PAYUDARA TIKUS PADA KARSINOGENESIS YANG DIINDUKSI DENGAN dimetilbenz(a)antrazena (DMBA)
}

\section{Gynura procumbens (Luor) Merr. LEAVES ETHANOLIC EXTRACT INHIBIT BREAST CANCER PROLIFERATION ON DMBA-INDUCED RAT MAMMARY CARCINOGENESIS}

\author{
Sri Tasminatun ${ }^{1}$, Edy Meiyanto ${ }^{{ }^{2}}$, Sugiyanto ${ }^{2}$ dan S. Handayani ${ }^{2}$ \\ ${ }^{1}$ Fakultas Kedokteran, Universitas Muhammadiyah Yogyakarta \\ ${ }^{2}$ Cancer Chemoprevention Research Center-Fakultas Farmasi, Universitas Gadjah Mada \\ meiyan_e@ugm.ac.id
}

\begin{abstract}
ABSTRAK
Penelitian sebelumnya menunjukkan bahwa ekstrak etanolik daun Gynura procumbens dapat menghambat pertumbuhan tumor payudara tikus yang diinduksi DMBA. Penelitian ini bertujuan untuk mengetahui efek ekstrak etanolik daun Sambung nyawa (Gynura procumbens (Luor) Merr) pada proliferasi sel kanker payudara tikus yang diinduksi dengan Dimetilbenz(a)antrazena (DMBA). Enam puluh ekor tikus betina galur SD umur 6 minggu dibagi menjadi 6 kelompok yaitu tanpa perlakuan, perlakuan DMBA saja dan empat kelompok perlakuan $D M B A+e k s t r a k$. Inisiasi DMBA dilakukan dengan dosis $20 \mathrm{mg} / \mathrm{kgBB}$ yang diberikan sebanyak 10 kali dengan frekuensi pemberian 2 kali setiap minggu. Mulai minggu ke-1 (post I) atau ke-6 (post II) kelompok perlakuan mendapat ekstrak etanolik daun Gynura procumbens dalam CMC 0,5\% seminggu 3 kali melalui oral dengan dosis $250 \mathrm{mg} / \mathrm{kgBB}$ dan $750 \mathrm{mg} / \mathrm{kgBB}$. Pada minggu $\mathrm{ke}-16$ tikus dikorbankan, jaringan payudara diambil untuk dibuat preparat histologi dengan teknik pewarnaan silver (AgNOR). Mean AgNOR (mAgNOR) dihitung pada setiap preparat tiap kelompok. mAgNOR kelompok perlakuan dibandingkan dengan mAgNOR kelompok tanpa perlakuan. Hasil penelitian menunjukkan ekstrak etanolik daun Gynura procumbens dengan dosis $250 \mathrm{mg} / \mathrm{kgBB}$ dan $750 \mathrm{mg} / \mathrm{kgBB}$ yang diberikan mulai minggu kesatu maupun ke-6 setelah inisiasi DMBA terakhir dapat mengurangi proliferasi sel kanker payudara tikus. Rata-rata mAgNOR kelompok tanpa perlakuan dan perlakuan DMBA saja masing-masing $0,8 \pm 0,34$ dan 2,7 $\pm 0,41$, mAgNOR post I kelompok dosis 250 dan dosis 750 masing-masing 1,4 $\pm 0,39$ dan 1,3 0,09, sedangkan mAgNOR post II kelompok dosis 250 dan dosis 750 masing-masing 1,6 $\pm 0,47$ dan 1,5 0,31. Pengamatan terhadap ekspresi COX-2 menunjukkan adanya penurunan pada kelompok perlakuan ekstrak dosis 250 dan $750 \mathrm{mg} / \mathrm{kgBB}$. Hasil-hasil tersebut menunjukkan bahwa ekstrak etanolik daun Gynura procumbens dapat menghambat proliferasi sel-sel tumor payudara yang kemungkinan berhubungan dengan penurunan ekspresi COX-2.
\end{abstract}

Kata kunci: Gynura procumbens, anti-karsinogenesis, proliferasi, AgNOR

\section{ABSTRACT}

The previous study shows that $\mathrm{G}$. procumbens leaves ethanolic extract inhibit breast cancer growth on DMBA-induced rat mammary carcinogenesis. The aim of the research is to examine the proliferation effect of $\mathrm{G}$. procumbens leaves ethanolic extract on DMBA-induced rat mammary carcinogenesis. Sixty female Sprague-Dawley rats at 6 weeks of age were randomized into six groups (untreated, DMBA treatment, and four groups with DMBA+extract treatment). DMBA (20 $\mathrm{mg} / \mathrm{kgBB}$ ) were given twice a week for 5 weeks. The beginning 1 week (post l) or 6 weeks (post II) post-DMBA, were administrated with $250 \mathrm{mg} / \mathrm{kgBB}$ and $750 \mathrm{mg} / \mathrm{kgBB}$ Gynura procumbens leaves ethanolic extract in $0.5 \%$ CMC-Na three times a week (po). At 16 weeks post-DMBA, rats were killed, and mammary tissues were classified histophatologically with AgNOR staining. Mean AgNOR (mAgNOR) were determinated from every sample in every group, and then mAgNOR on treated groups were compared with mAgNOR on untreated group. The result shows that mean of mAgNOR in untreated, DMBA, DMBA+250 mg/kg BB extract and DMBA+750 mg/kgBB extract group in post I and post II are $0.8 \pm 0.34,2.7 \pm 0.41,1.4 \pm 0.39,1.3 \pm 0.09,1.6 \pm 0.47$, and 1.5 \pm 0.31 respectively. Observation of COX-2 expression shows that $250 \mathrm{mg} / \mathrm{kg} B B$ and $750 \mathrm{mg} / \mathrm{kgBB}$ Gynura procumbens leaves ethanolic extract groups decrease COX-2 expression compared with $D M B A$ group. The result shows that $\mathrm{G}$. procumbens ethanolic leaves ethanolic extract inhibit breast cancer proliferation on DMBA-induced rat mammary carcinogenesis possibly related to decrease of COX-2 expression.

Key words: Gynura procumbens, anticarcinogenesis, proliferation, AgNOR

12 PHARMACON, Vol. 13, No. 1, Juni 2012, Tasminatun, S. et al. (12-17) 


\section{PENDAHULUAN}

Penelitian terhadap tanaman Gynura procumbens (Lour) Merr menunjukkan bahwa ekstrak etanolik daun tanaman tersebut mampu menghambat karsinogenesis pada tahap inisiasi hingga menurunkan insidensi dan perbanyakan nodul tumor payudara tikus (Meiyanto, et al., $2007^{\mathrm{a}}$ ). Pada pemberian post inisiasi awal ekstrak tersebut juga masih menunjukkan efek penurunan jumlah nodul tumor, sedang pada pemberian post inisiasi akhir efeknya sudah tidak bermakna (Meiyanto, et al, 2007 ${ }^{b}$. Fenomena ini disebabkan oleh induksi kanker payudara dengan karsinogen DMBA menggunakan multiple dose yaitu 20 $\mathrm{mg} / \mathrm{kgBB}$ sebanyak 10 kali. Dosis DMBA ini lebih besar bila dibandingkan dengan dosis yang digunakan oleh peneliti sebelumnya (Singletary, et al, 1997) yaitu single dose 30 $\mathrm{mg} / \mathrm{kgBB}$, sehingga penghambatan karsinogenesis oleh ekstrak etanolik daun Gynura procumbens tidak dapat diamati secara makroskopis. Namun demikian dengan terlihatnya kecenderungan penurunan jumlah nodul tumor pada penelitian tersebut kemungkinan terdapat perubahan fisiologi pada tingkat seluler, misalnya sifat proliferatif sel-sel tumor yang ada.

Telah dilaporkan pada penelitian terdahulu bahwa ekstrak etanolik daun $G$. procumbens mengandung flavonoid dan terbukti mampu menghambat pertumbuhan sel kanker payudara secara in vitro (Sugiyanto et al, 2003; Jenie and Meiyanto, 2007). Ekstrak tersebut secara in vivo juga menunjukkan efek penghambatan karsinogenesis kanker paru dan payudara yang berarti bahwa ekstrak tersebut juga mampu memberikan efek secara sistemik.

Salah satu indikator penting dalam mempelajari sifat keganasan sel kanker adalah kemampuan proliferasinya (Meiyanto and Septistyani, 2005). Proliferasi sel-sel kanker sangat dipengaruhi oleh perubahan ekspresi protein yang ada di dalam sel (Hanahan and Weinberg, 2000). yang salah satunya adalah ekspresi COX-2 yang berlebihan (Meiyanto, 1999). Pada kanker payudara, ekspresi COX-2 juga sering dijumpai dan berperan dalam peningkatan proliferasi dan metastasis (Davies et al, 2002). Penelitian ini bertujuan untuk mengamati efek ekstrak etanolik daun $G$. procumbens pada proliferasi (dengan metode AgNOR) dan ekspresi COX-2 sel-sel tumor epitel payudara tikus yang diinduksi dengan DMBA.

\section{METODE PENELITIAN}

Bahan uji karsinogenesis. Daun tanaman Gynura procumbens, (Lour) Merr yang diperoleh dari daerah Ngaglik Sleman Yogyakarta dikeringkan pada temperatur tidak lebih dari $60{ }^{\circ} \mathrm{C}$ kemudian di ekstraksi dengan etanol $96 \%$ (p.a.) hingga di peroleh ekstrak etanolik. Untuk pembuatan model kanker payudara digunakan DMBA (7,12-dimetilbenz(a)ntrasen) (Sigma)

Subyek uji. Subjek uji yang digunakan adalah tikus betina galur Sprague Dawley umur 4 minggu dengan berat badan 40-60 g yang diperoleh dari BPOM Jakarta, yang kemudian di pelihara dalam kandang hewan Laboratorium Farmakologi dan Toksikologi Fakultas Farmasi UGM, Yogyakarta hingga cukup umurnya untuk diberi perlakuan.

\section{Jalan Penelitian \\ Induksi karsinogenesis dengan DMBA dan perlakuan dengan ekstrak etanol daun Gynura procumbens, (Lour) Merr.}

Enam puluh tikus betina (Female) umur 50 hari dibagi menjadi 6 kelompok secara random. Kelompok I digunakan sebagai kelompok tanpa perlakuan yang hanya diberi makanan kontrol saja, yaitu pelet AD2 yang diproduksi oleh PT COMFED Surabaya. Kelompok II (perlakuan DMBA saja), III dan IV (perlakuan pada tahap karsinogenesis awal: post-I), dan V dan VI (perlakuan pada tahap karsinogenesis lanjut: post-II) diberi DMBA (20 $\mathrm{mg} / \mathrm{kgBB}$, i.g. dalam minyak jagung) dan ekstrak. Inisiasi DMBA dilakukan 2 kali seminggu selama 5 minggu. Kelompok III dan IV diberi ekstrak masing-masing dengan dosis $250 \mathrm{mg} / \mathrm{KgBB}$ dan $750 \mathrm{mg} / \mathrm{KgBB}$ pada minggu ke-1 setelah DMBA terakhir, hingga akhir pengamatan. Kelompok V dan VI, diberi ekstrak dengan peringkat dosis yang sama dengan post-inisiasi I pada minggu ke-6 setelah DMBA terakhir hingga akhir pengamatan. Tikus ditimbang setiap minggunya, dan mulai minggu ke-1 setelah pemberian DMBA dilakukan palpasi payudara setiap minggu untuk mengamati perkembangan tumor sampai minggu ke-16 (modifikasi dari 3 dan 11).

\section{Pemeriksaan aktivitas proliferasi dengan metode AgNOR}

Irisan jaringan dari organ payudara tikus yang diperoleh dari proses jaringan direndam dalam buffer sodium sitrat $(\mathrm{pH} 6,0)$ kemudian diinkubasi di dalam autoclave pada suhu $120^{\circ} \mathrm{C}$ selama 20 menit. Setelah didinginkan sampai suhu $37^{\circ} \mathrm{C}$, slide kemudian direndam dalam larutan pengecatan perak yang terdiri dari 1 bagian volume gelatin $0,5 \%$ dalam asam formiat $1 \%$ dan 2 bagian larutan perak nitrat 50 $\%$ dan diinkubasi pada suhu $37^{\circ} \mathrm{C}$, selama 11 menit. Reaksi dihentikan dengan mencuci slide menggunakan aqua bidestilata untuk menghilangkan presipitat perak non-spesifik. 
Selanjutnya, semua jaringan didehidrasi menggunakan etanol dengan konsentrasi yang dinaikkan secara bertingkat, dibersihkan dengan xylene dan ditempelkan bersama medium sintetis (Bankfalvi et al, 2002). Pembuatan preparat AgNOR dilakukan di Laboratorium Patologi Anatomi Fakultas Kedokteran UGM.

Preparat AgNOR digunakan untuk mengamati tingkat proliferasi sel epitel payudara dengan menghitung dot hitam di dalam inti sel dan menghitung jumlah sel. Preparat hasil pewarnaan AgNOR selanjutnya diamati dengan mikroskop binokuler Olympus dengan perbesaran $1000 \times$ dan bantuan minyak imersi. Pemeriksaan dilakukan pada 3 lapang pandang dengan menghitung jumlah seluruh titik hitam pada minimal 100 sel pada tiap lapang pandang kemudian dirata-rata dengan cara membagi jumlah seluruh titik hitam dengan jumlah sel yang diamati. Perhitungan dilakukan terhadap Mean AgNOR (mAgNOR), yaitu jumlah dot dihitung pada setiap 100 sel tiap preparat. Mean AgNOR kelompok perlakuan dibandingkan dengan mean AgNOR kelompok kontrol positif. Mean AgNOR dianalisis dengan dengan uji statistik Non Parametrik Kruskal Wallis dengan taraf kepercayaan 95\% dilanjutkan dengan Man Whitney Test.

\section{Pemeriksaan ekspresi protein COX-2}

Prosedur pemeriksaan ekspresi protein COX-2 dilakukan di Laboratorium Patologi Anatomi RS Dr. Sardjito Yogyakarta. Organ payudara 'frozen section' diiris dan difiksasi dengan aseton. Preparat direndam berturutturut dalam metanol dan aseton kemudian dicuci dengan PBS. Selanjutnya preparat direndam dalam $3 \%$ hidrogen peroksida $\left(\mathrm{H}_{2} \mathrm{O}_{2}\right.$ dalam metanol) selama 20 menit, lalu dicuci dengan PBS sebanyak 2 kali dan diinkubasikan dalam normal mouse serum (1:50) selama 5 menit. Selanjutnya normal mouse serum dibuang, preparat ditetesi dengan antibodi primer (Primer Antibodi Monoklonal anti COX-2Santa cruz) dengan pengenceran 1:100 dan diinkubasikan minimal selama 60 menit. Setelah dicuci dengan PBS, preparat diinkubasi dengan biotin, kemudian dalam streptavidinperoksidase, dan kemudian dalam DAB. Ekspresi COX-2 diamati menggunakan mikroskop cahaya (Olympus ${ }^{\circledR}$ DP 12 Microscope Digital Camera System). Ekspresi protein COX2 pada jaringan kanker payudara dianalisis secara kualitatif dengan membandingkan intensitas warna coklat antar kelompok perlakuan.

\section{HASIL DAN PEMBAHASAN \\ Efek ekstrak Gynura procumbens pada proliferasi sel kanker.}

Untuk mengetahui tingkat proliferasi sel kanker payudara dilakukan pemeriksaan jumlah AgNOR. NOR (Nuclear Organizer Region) yaitu loop DNA pada tangan pendek kromosom akrosentrik (13, 14, 15, 21 dan 22) yang berhubungan dengan aktivitas gen ribosomal RNA, sintesa protein dan proliferasi sel. Dengan pewarnaan silver, NOR akan tampak sebagai titik hitam (black dot) (Gambar 1) yaitu berupa AgNOR yang kemudian dapat dihitung (Ervin and Elza, 2003). Jumlah NOR tiap sel pada perlakuan ekstrak (Gambar 1C) terlihat lebih sedikit dibanding jumlah NOR pada kelompok DMBA (Gambar 1B). Hal ini menunjukkan bahwa pemberian ekstrak mampu menghambat proliferasi sel kanker payudara tikus.

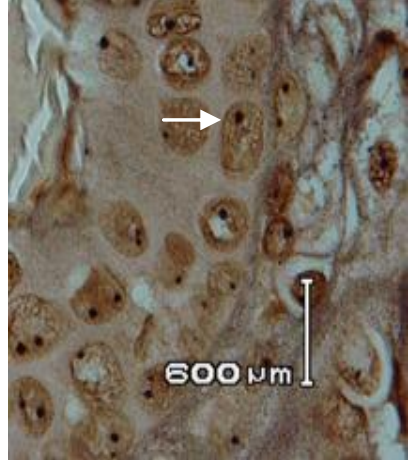

A

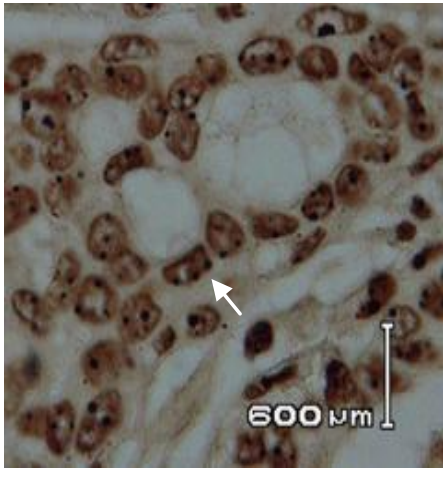

B

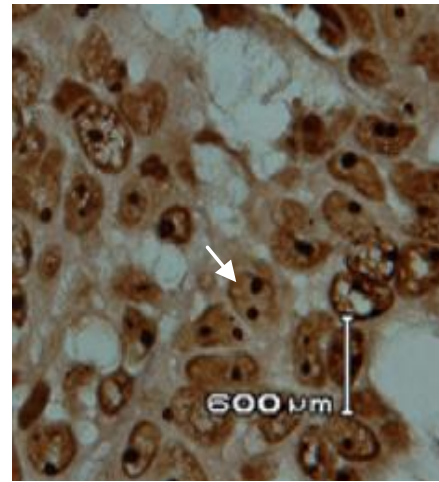

C

Gambar 1-Efek pemberian ekstrak terhadap jumlah black dot hasil pengecatan AgNOR. Pengecatan AgNOR dilakukan seperti pada metodologi terhadap preparat dibuat dari jaringan tumor kelenjar payudara tikus pada minggu ke-16 setelah pemberian DMBA terakhir. Pengamatan dilakukan dengan mikroskop cahaya dengan perbesaran 1000x. A adalah preparat dari kelompok tikus kontrol tanpa perlakuan; B adalah preparat tikus perlakuan DMBA saja, dan C adalah preparat tikus dengan perlakuan DMBA+ekstrak post II dosis $250 \mathrm{mg} / \mathrm{kgBB}$. Titik hitam (tanda panah) menunjukkan bagian NOR yang merepresentasikan aktivitas proliferasi sel. 
Tabel 1-Mean AgNOR kelompok Kontrol DMBA dan perlakuan $G$. Procumbens

\begin{tabular}{ll}
\hline KELOMPOK & Mean AgNOR \pm SD \\
\hline DMBA & $2.7 \pm 0,41$ \\
POST I.250 & $1.4 \pm 0,39$ \\
POST I.750 & $1.3 \pm 0,09$ \\
POST II.250 & $1.6 \pm 0,47$ \\
POST II.750 & $1.5 \pm 0,31$ \\
\hline
\end{tabular}

Pemeriksaan AgNOR dilakukan pada 3 lapang pandang dengan menghitung jumlah seluruh titik hitam pada minimal 100 sel pada tiap lapang pandang kemudian dirata-rata dengan cara membagi jumlah seluruh titik hitam dengan jumlah sel yang diamati. Rata-rata mAgNOR kelompok tanpa perlakuan dan perlakuan DMBA saja masing-masing $0,8 \pm$ 0,34 dan $2,7 \pm 0,41$, mAgNOR post I kelompok dosis 250 dan dosis 750 masing-masing 1,4 \pm 0,39 dan $1,3 \pm 0,09$, sedangkan mAgNOR post II kelompok dosis 250 dan dosis 750 masingmasing 1,6 $\pm 0,47$ dan $1,5 \pm 0,31$ (tabel 1). Pemeriksaan aktivitas proliferasi dengan metode AgNOR ini menunjukkan penurunan angka mAgNOR kelompok DMBA+ekstrak dibanding kelompok DMBA saja hingga $40 \%$. Penurunan tersebut terjadi pada semua dosis yang diberikan baik pada post I maupun post II. Analisis statistik non parametrik Kruskal Wallis dengan taraf kepercayaan 95\% dilanjutkan dengan Man Whitney Test angka mAgNOR diperoleh hasil bahwa angka mAgNOR berbeda secara bermakna. Ini berarti pemberian ekstrak etanolik daun Gynura procumens dapat mengurangi tingkat proliferasi sel kanker payudara.

\section{Pengaruh pemberian ekstrak terhadap ekspresi COX-2}

Untuk mengetahui mekanisme penghambatan proliferasi sel kanker oleh Gynura procumbens dilakukan pemeriksaan ekspresi protein COX-2. Pemeriksaan penghambatan ekspresi COX-2 ekstrak etanolik Gynura procumbens dilakukan dengan melakukan pengecatan menggunakan antibodi anti COX-2 terhadap sel kanker payudara tikus. Sel kanker yang mengekspresikan COX-2 akan memberikan warna coklat atau gelap, sedangkan yang tidak mengekspresikan COX-2 memberikan warna ungu.

Hasil pengamatan menunjukkan bahwa pada tikus yang hanya diberi perlakuan DMBA sel-sel pada jaringan tumornya terlihat berwarna kecoklatan yang menunjukkan adanya ekspresi COX-2 yang relatif tinggi (Gambar 2A). Adapun pada sel-sel tumor dari tikus yang diberi perlakuan ekstrak menunjukkan warna coklat yang lebih tipis (Gambar 2B-2C). Hal ini berarti ekspresi COX-2 pada sel-sel yang diberi ekstrak tersebut lebih rendah dari pada sel-sel yang diberi perlakuan DMBA saja. Pemberian ekstrak pada kedua dosis terlihat menurunkan ekspresi COX-2 pada sel-sel tumor epitel payudara tikus.

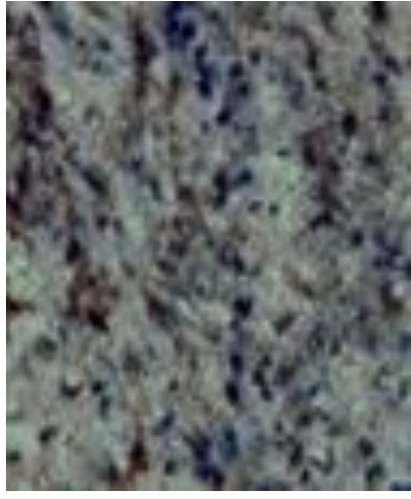

A

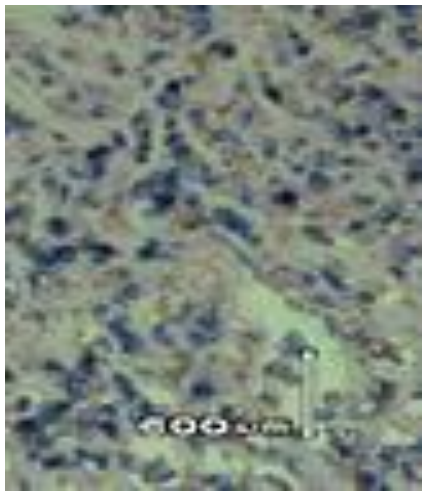

B

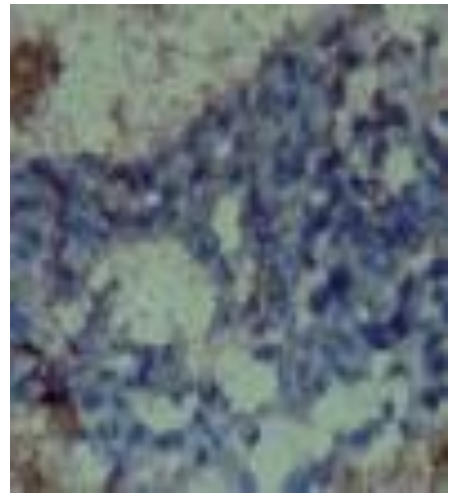

C

Gambar 2-Efek pemberian ekstrak post inisiasi terhadap ekspresi protein COX-2 pada kanker payudara. Pengamatan ekspresi COX-2 pada jaringan payudara tikus dilakukan dengan metode IHC yang dilakukan seperti pada metode dan diamati di bawah mikroskop cahaya dengan perbesaran 400x. A adalah perlakuan DMBA saja, $B$ adalah perlakuan DMBA+ekstrak Post I. 250mg/kgBB, dan C adalah perlakuan DMBA+ekstrak Post I $750 \mathrm{mg} / \mathrm{kgBB}$. Warna coklat menunjukkan adanya ekspresi COX-2. 
Hasil penelitian sebelumnya menunjukkan bahwa ekstrak etanolik daun Gynura procumbens setelah inisiasi pada kanker payudara tikus terinduksi DMBA mempunyai kecenderungan menurunkan insidensi tumor sebesar 10-20 \% dan menurunkan tumour multiplicity meskipun secara statistik tidak memperlihatkan perbedaan yang nyata (Meiyanto et al, 2007 ${ }^{\mathrm{b}}$ ). Pengamatan aktifitas proliferasi sel kanker dengan metode AgNOR diperoleh hasil tingkat aktifitas proliferasi sel kanker kelompok ekstrak etanolik daun Gynura procumbens mengalami penurunan secara bermakna dibanding kelompok kontrol DMBA. Pemeriksaan ekspresi COX-2 juga menunjukkan adanya penurunan ekspresinya.

Penelitian Iskander et al (2002) menyimpulkan bahwa ekstrak etanolik daun Gynura procumbens mempunyai efek antiinflamasi. Beberapa penelitian menunjukkan bahwa fitokimia yang mempunyai efek antiinflamasi berpotensi sebagai agen kemopreventif. Beberapa diantaranya adalah curcumin dalam Curcuma longa L., gingerol dalam Zingiber officinale dan capsaicin dalam Capsicum annuum (Surh et al, 2002) yang bekerja dengan menghambat enzim siklooksigenase atau cyclooxygenase (COX).

Dua isoform siklooksigenase yang telah diidentifikasi adalah siklooksigenase-1 (COX-1) dan siklooksigenase-2 (COX-2). Keduanya mengkatalisis sintesa prostaglandin dari asam arakidonat. COX-1 diekspresikan pada seluruh jaringan mamalia dan berperan penting pada proses fisiologis. Adapun COX-2 berperan pada proses inflamasi, induksi enzim dan terlibat pada beberapa kasus penyakit (Dubois et al, 1998). Pada sejumlah kanker termasuk payudara, kolon, pankreas dan prostat terjadi over ekspresi COX-2. Kelebihan ekspresi COX2 dan sintesis $\mathrm{PGE}_{2}$ memperantarai transformasi sel epitel neoplasma dengan meningkatkan laju proliferasi dan metastasis (Davies et al, 2002).

Penelitian ini menunjukkan bahwa ekstrak etanolik daun Gynura procumbens mampu menekan ekspresi protein COX-2. Penghambatan proliferasi sebagai akibat menurunnya ekspresi COX -2 didukung oleh hasil penelitian terjadinya penurunan angka mean AgNOR kelompok yang diberi ekstrak etanolik daun $G$. procumbens yang berarti terjadi penurunan tingkat aktifitas proliferasi sel kanker. Mekanisme penghambatan ekspresi COX-2 dapat tejadi melalui penghambatan fosforilasi IKB oleh IKK. Protein IKK termasuk golongan protein kinase sehingga memungkinkan dihambat oleh senyawa flavonoid (Sukla and Gupta, 2004). Dengan tidak terfosforilasinya Ik-B maka NF-kB yang berikatan dengan $\mathrm{I}_{\kappa} \mathrm{B}$ tidak dapat menginduksi ekspresi COX-2. Flavonoid dalam Gynura Procumbens diduga menghambat fosforilasi $I_{\kappa} B$. Hal ini perlu dibuktikan dengan penelitian lebih lanjut.

\section{KESIMPULAN}

Ekstrak etanolik daun Gynura procumbens yang diberikan seminggu 3 kali dengan dosis $250 \mathrm{mg} / \mathrm{kgBB}$ dan $750 \mathrm{mg} / \mathrm{kgBB}$ pada kanker payudara tikus terinduksi DMBA dapat menurunkan tingkat aktifitas proliferasi sel kanker secara signifikan dengan rata-rata mAgNOR kelompok tanpa perlakuan dan perlakuan DMBA saja masing-masing 0,8 \pm 0,34 dan 2,7 \pm 0,41, mAgNOR post I kelompok dosis 250 dan dosis 750 masing-masing 1,4 \pm 0,39 dan $1,3 \pm 0,09$, sedangkan mAgNOR post II kelompok dosis 250 dan dosis 750 masingmasing 1,6 $\pm 0,47$ dan 1,5 $\pm 0,31$. Secara kualitatif, ekstrak etanolik daun Gynura procumbens juga mampu menurunkan ekspresi COX-2.

\section{DAFTAR PUSTAKA}

Bankfalvi A., Giuffre G., Öfner D., Diallo R., Poremba C., Buchwalow I. B., Barresi V., Bocker W., and Tuccari G. Relationship between HER2 status and proliferation rate in breast cancer assessed by immunohistochemistry, fluorescence in situ hybridisation and standardised AgNOR analysis. International J. Of Onc. 2002.23:1285-1292

Davies, G., Martin, L.A., Sacks, N. and Dowsett, M. Cyclooxygenase-2(COX-2), Aromatase and Breast Cancer: A Possible Role in for COX-2 Inhibitors in Breast Cancer Chemoprevention. Ann Oncol. 2002.13:669-678

Dubois, R.N., Abramson, S.B., Crofford, L., Gupta, R.A., Simon, L.S., Van de Putte, L.B., and Lipsky, P.E. Cyclooxygenase in Biology and Disease. FASEB J. 1998.12:1063-1073

Hanahan, D. and Weinberg, R.A. The Hallmarks of Cancer. Cell. 2000.100:57-70

Iskander MN.,Song Y.,Coupar IM and Jiratchariyakul W. Antiinflammatory screening of the medicinal plant Gynura procumbens. J Plant Foods Hum Nutr. 2002.57(3-4):233-244 
Jenie, R.I. and Meiyanto, E. Aplikasi ko-kemoterapi ekstrak etanolik daun Gynura procumbens (Lour.) Merr. pada sel kanker payudara. Maj.Farmasi Indon. , 2007.18(2):81-87

Meiyanto E., Susilowati S., Tasminatun S, Murwanti R., dan Sugiyanto. Efek kemopreventif ekstrak etanolik daun Gynura procumbens (Lour.) Merr. pada karsinogenesis kanker payudara tikus. Maj.Farmasi Indon. 2007. 18(3):154-161

Meiyanto E., Susilowati S., Tasminatun S, Murwanti R., dan Sugiyanto. Penghambatan karsinogenesis kanker payudara tikus terinduksi DMBA pada fase post inisiasi oleh ekstrak etanolik daun Gynura procumbens (Lour.) Merr. MFI. 2007. 18(4):169-175

Rizali Ervin dan Auerkari Elza I. Teknik Pewarnaan Silver (AgNOR) Sebagai Salah Satu Cara Menentukan Aktivitas Proliferasi Sel Tumor dan Apoptosis. Jurnal Kedokteran Gigi Indonesia. 2003. 10(3):41-45

Singletary,K., Macdonald,C., and Wallig,M. The Plasticizer Benzyl Butyl Phtalate (BBP) Inhibits 7,12-dimethylbenz( $\alpha$ )anthracene (DMBA)-induced rat Mammary DNA Adduct Formation and Tumorigenesis. Carsinogenesis. 1997. 18(8):1669-1673

Sugiyanto, Sudarto, B., Meiyanto, E., Nugroho,AE dan Jenie,U.A., 2003, Aktivitas antikarsinogenik senyawa yang berasal dari tumbuhan, Maj.Farmasi Indon., 14 (4):216-225

Meiyanto, E., and Septistyani, E.P. Efek antiproliferatif dan apoptosis fraksi fenolik ekstrak etanolik daun Gynura procumbens terhadap sel HeLa. Artocarpus. 2005. 5(2):74-80

Meiyanto, E. Kurkumin sebagai anti-kanker: menelusuri mekanisme aksinya (Review). MFI. 1999. 10(4):224-23

Surh, Y. Anti-tumor promoting potential of selected of spice ingredients with antioxidative and antiinflammatory activities: a short review. Food and Chem. Tox. 2002. 40:1091-1097

Sukla, S., and Gupta, S. Suppression of Constitutive and Tumor Necrosis Factor K-Induced Nuclear Factor (NF)-KB Activation and Induction of Apoptosis by Apigenin in Human Prostate Carcinoma PC-3 Cells: Correlation with Down-Regulation of NF-KB-Responsive Genes. Clinical Cancer Research. 2004. 10:3169-317. 